\title{
Correlation between Hepatitis C Virus Antibodies in Saliva and Serum: A Safe Method for Epidemiological Studies
}

\author{
Tükrükten Ayrıștırılan Hepatit C Virüs Antikorları ile Serum HCV-RNA Arasındaki \\ Korelasyonun Belirlenmesi
}

\author{
(1) Oya Özlem Eren Kutsoylu, (1) Ziya Kuruüzüm, (1) Ayşe Yüce \\ Dokuz Eylül University Faculty of Medicine, Department of Infectious Diseases and Clinical Microbiology, Izmir, Turkey
}

\begin{abstract}
Objectives: Hepatitis C virus ( $\mathrm{HCV}$ ) infection is an increasing public health problem in developing countries. A non-invasive method is required as blood sampling is an invasive method for detecting HCV antibodies. In this report, we examined the performance of a commercially available serological kit to detect HCV antibodies in saliva as a possible alternative to serum for epidemiological studies. Materials and Methods: A total of 150 paired oral fluid and blood samples were collected from 75 anti-HCV-positive and 75 antiHCV-negative individuals. Homemade swabs were used for saliva sampling instead of commercial products.

Modified Ortho HCV 3.0 SAVe ELISA kit was used to detect HCV antibodies in saliva, and blood samples were analyzed for anti-HCV and HCV-RNA.

Results: The sensitivity and specificity of this assay were $86.7 \%$ and $86.7 \%$ in saliva. Out of 38 participants who were positive for HCV-RNA in serum, 36 were also positive for HCV antibodies in saliva.

Conclusion: The implementation of a non-invasive method such as saliva collection is easy, economical, and can be done by unskilled personnel. According to our sensitivity and specificity results, the modified ELISA method for anti-HCV detection in saliva with the use of a different saliva collection system can be an alternative technique for epidemiological surveys.

Keywords: Hepatitis C virus, epidemiology, antibody, Saliva
\end{abstract}

ÖZ

Amaç: Tükrükte hepatit $\mathrm{C}$ virüsüne $(\mathrm{HCV})$ karşı bulunan antikorlar ile kandaki HCV-RNA ve antikorları arasındaki ilişkiyi araştırmak ve epidemiyolojik çalışmalar ön planda olmak üzere saha çalışmalarında bu yöntemin kullanılabilirliğini saptamaktır.

Gereç ve Yöntemler: Polikliniğimize başvuran 75 anti-HCV (+) ve 75 anti-HCV (-) olgunun tükrük ve kan örnekleri alındı. Tükrük almak için çeşitli ticari kitler yerine hastaların ağız bakımı için geliştirilmiş olan sünger çubuklar kullanıldı. Alınan örnekler modifiye Ortho HCV 3.0 SAVe ELISA (Ortho Clinical Diagnostics, US) kiti ile çalışıldı. Kan örnekleri ise uygun koşullarda alınıp anti-HCV ve HCV-RNA tetkikleri çalışılmak üzere hastanemiz merkez laboratuvarına gönderildi.

Bulgular: Çalışılan 75 anti-HCV (+) hastanın otuzsekizinde $(\% 50,7)$ HCV-RNA (+), 65'inde $(\% 86,7)$ tükrük anti-HCV (+) saptandı. Kontrol grubundaki 75 olgudan 10'unun (\%13,3) tükrüğünde anti-HCV (+) saptandı. Serum anti-HCV altın standart olarak kabul edildiğinde tükürük anti-HCV duyarlılı̆ı \%86,7 ve seçiciliği \%86,7 olarak sonuçlandı. HCV-RNA (+) olan 38 hastanın 36'sında $(\% 94,7)$ tükrük anti-HCV (+) bulundu.

Sonuç: Anti-HCV'nin tükrükte araştırıması oldukça yeni bir tanı yöntemi olup tükrük örneğinin alınması kolay, acısız, hızı ve daha az teknik ekipman gerektiren bir yöntemdir. Non-invaziv bir teknik olması, bulaş riski oluşturmaması, eğitimli personele intiyaç duyulmadan kişinin kendi kendine örnek almasına olanak tanıması bu tekniği saha çalışmaları için çekici kılmaktadır. Çalışmamızın duyarlıık ve seçicilik sonuçlarına göre bu yöntem epidemiyolojik araştırmalarda kullanılmaya aday alternatif bir tekniktir. Ülkemizde bu konu ile ilgili yapılan araştırma olmaması, ayrıca hazır tükrük alma kiti kullanılmadan yapılan ilk araştırma olması nedeniyle de ayrı bir yeri bulunmaktadır.

Anahtar Kelimeler: Hepatit C virüsü, epidemiyoloji, antikor, tükrük

Eren Kutsoylu 00̈, Kurü̈züm Z, Yüce A. Correlation between Hepatitis C Virus Antibodies in Saliva and Serum: A Safe Method for Epidemiological Studies. Viral Hepat J. 2020;26:65-68. 


\section{Introduction}

Hepatitis C virus (HCV) infection is an important public health problem, with an estimated 170 million people infected worldwide (1). Although available data are limited, it is estimated prevalence of $\mathrm{HCV}$ is higher in developing than developed countries (2). Common risk factors for HCV infection are blood transfusion and intravenous drug use, and sexual and vertical transmission (3). HCV infection primarily affects liver and can cause cirrhosis and hepatocellular carcinoma later in life.

Although sensitive and specific serologic tests are available, difficulty in obtaining blood samples and risk of disease transmission to health personnel through needlestick injury are disadvantages that limit their acceptance outside a clinical setting. Therefore, a safer, non-invasive alternative to blood sampling is required. Collection of saliva is easy, non-invasive, painless and safe to carry out. In epidemiological studies, especially those involving screening large populations, saliva sampling is quicker than blood sampling and there is no need for specialized staff (4).

Several saliva collection methods have been developed, e.g. Omni-SAL (Saliva Diagnostic Systems, Inc., Vancouver, WA, USA), Orapette (Trinity Biotech, Dublin, Ireland), OraSure (Epitope Technologies, Inc., Bethlehem, PA, USA), and Salivette (Sarsted Ltd., Leicester UK). The study reports use of an in-house saliva collection device, which is easy to produce and offers a more affordable method for clinical and epidemiology studies conducted in developing countries.

\section{Materials and Methods}

\section{Study group}

The study group consisted anti-HCV seropositive and anti-HCV seronegative patients ( $n=75$ for both groups). HCVseropositive patients were those undergoing follow-up visits at the Infectious diseases and clinical microbiology outpatient clinic. HCV-seronegative participants were those who attended the same outpatient clinic for other reasons. The study was approved by the Institutional Ethical Comittee Dokuz Eylül University (approval number: 200895). Prior informed consent was obtained from all participating patients, who were $>18$ years of age.

\section{Sample collection}

Each participant donated two blood samples (16 mL) and one saliva sample $(6 \mathrm{~mL})$, collected at the same time. Serum from one sample was stored at $-20{ }^{\circ} \mathrm{C}$ and the other at $-80{ }^{\circ} \mathrm{C}$ until used. Saliva samples were collected using sterile foam swabs $(3 \mathrm{cmX}$ $1.5 \mathrm{~cm} \times 5.5 \mathrm{~cm}$ ). Patient was requested to hold the foam swab in mouth for two minutes, then swab was placed in one $\mathrm{ml}$ aliquot of Universal Transport Medium (Copan Italia S.p.a., Brescia, Italy), centrifuged at $3.000 \mathrm{~g}$ for 15 minutes and supernatant stored at $-20{ }^{\circ} \mathrm{C}$ until used.

\section{Laboratory assays}

Serum samples were tested for anti-HCV antibodies using an Architect i2000 SR kit (Abbott Laboratories, Ltd. Saint-Laurent, Québec, Canada). Anti-HCV-positive serum samples were then tested for presence of HCV-RNA using Artus HCV-RG-RT-PCR assay kit (QIAGEN Gmbh, Hilden, Germany).
Saliva samples were tested for anti-HCV antibodies using Ortho HCV 3.0 SAVe ELISA kit (Ortho Diagnostics, Amersham, UK) with a modified protocol to increase sensitivity (5). In brief, $110 \mu$ l aliquot of saliva solutions and control samples were incubated for 16-20 hours at ambient temperature $\left(15-30^{\circ} \mathrm{C}\right)$ with shaking in a 96-well microtiter plate. Then plate was washed with buffer (supplied by the manufacturer), $200 \mu$ aliquot of horseradish peroxidase-conjugated murine anti-human immunoglobulin $\mathrm{G}(\mathrm{lgG})$ monoclonal antibodies was added to each well, and plate was incubated for another three hours at ambient temperature, washed as described above before addition to each well of $200 \mu \mathrm{l}$ of substrate and incubation for 30 minutes at room temperature in the dark. Reaction was terminated with $50 \mu$ of $4 \mathrm{M}$ sulfuric acid solution and $A_{490 \mathrm{~nm}}$ measured with a microplate spectrophotometer (Multiskan FC Microplate Photometer; Thermo Fisher Scientific Oy, Oulu, FINLAND). Final $A_{490 \mathrm{~nm}}$ values determined by a receiver operating characteristic (ROC) curve analysis.

\section{Statistical Analysis}

Detection of anti-HCV antibodies in serum samples was used as a gold standard for the assessment of sensitivity, specificity, positive predictive value (PPV), and negative predictive value (NPV) of the Ortho HCV 3.0 SAVe ELISA assay (Ortho Diagnostics) in saliva. Cut-off value was calculated according to ROC curve analysis as value with highest specificity and the sensitivity. Values $\geq 0.133$ were considered positive and values $<0.133$ considered negative.

\section{Results}

Mean age of the participants was $57 \pm 12.5$ years in the test group and $58 \pm 17$ years in control group, with $47 \%$ males. Nine participants in the test group were in a hemodialysis program. All participants had negative Human Immunodeficiency Virus serology.

Difference between mean $A_{490 \mathrm{~nm}}$ value $(1.32 \pm 1.023$ and $0.17 \pm 0.24)$ of anti-HCV antibody ELISA in saliva samples of test and control group respectively is statistically sigificant (MannWhitney $U$ test; mwu: 27, p-value <0.001), as was in serum samples (data not shown). Sensitivity, specificity, NPV and PPV value of saliva samples employing the modified Ortho HCV 3.0 SAVe ELISA (Ortho Diagnostics) was $87 \%$ for each parameter (Table 1).

In the HCV-seropositive group, 38 (51\%) patients were HCVRNA positive, of whom 36 (95\%) were positive for anti-HCV antibodies in saliva. Of the 37 patients who were HCV-RNA negative, 29 (78\%) had anti-HCV antibodies in saliva. Similar relationship was observed between serum HCV-RNA positivity

Table 1. Anti-HCV antibody-positive and -negative samples from participants at the infectious diseases and clinical microbiology outpatient clinic of a university hospital in İzmir, Turkey

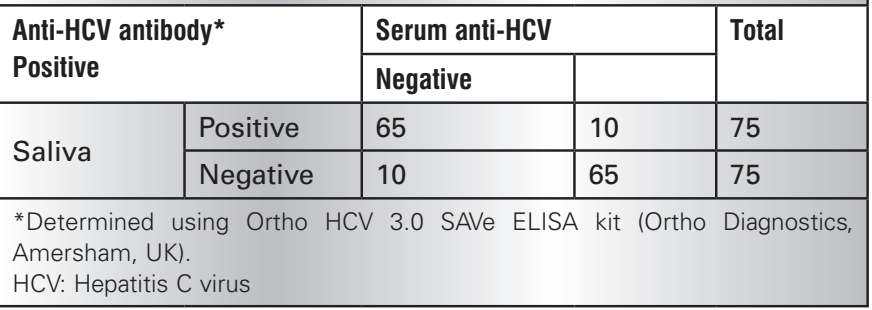


and $A_{490 \mathrm{~nm}}$ values in saliva. Difference between mean $A_{490 \mathrm{~nm}}$ value $(1.65 \pm 0.94$ and $0.66 \pm 0.78)$ in saliva of test patients with positive and negative serum HCV-RNA respectively is also statiscally significant (Mann-Whitney $U$ test; mwu: 277.5, p-value <0.001). Higher mean $A_{490} \mathrm{~nm}$ value was observed in serum HCV-RNA positive than negative group.

\section{Discussion}

Saliva sampling is an easier and less invasive method compared to serum sampling. Previous reports indicate that saliva is an appropriate specimen diagnosis of different infectious diseases, in particular viral infections that pose a hazardous risk to health personnel in the situation of needle prick accidents (5). In addition, there are various devices for collecting saliva as well as commercial tests geared for assaying saliva samples (Table 2).

In our study, an in-house saliva collecting device consisting of a sterile foam placed in a subject's mouth was employed, a lowcost alternative to more expensive commercial saliva collecting devices. Using a saliva-dedicated commercial ELISA kit, there was good concordance between paired serum and saliva samples in detecting anti-HCV antibodies. Sensitivity and specificity of this assay for saliva samples were high (>85\%).

In comparison with serum, Ig levels are 800-1000 folds lower in oral fluid, where IgA is predominant (6). Lee et al. (7) evaluated the use of an HCV antibody rapid test device with venous blood, fingerstick blood, serum, plasma, and oral fluid. They observed a slightly lower sensitivity (98.1\%) with oral fluid, which they attributed to conditions of oral health, use of oral care products, and consumption of food and drink (7). Cha et al. (8) used the HCV antibody rapid test device with oral fluid and reported a clinical sensitivity was $97.8 \%$. This may be responsible for low sensitivity of HCV antibody detection in saliva in the event of low anti-HCV antibody titers and negative HCV-RNA levels $(9,10)$. It is worth noting a patient negative for saliva anti-HCV antibody was HCVRNA positive and had previously been diagnosed as rheumatoid arthritis and treated with immunosuppressive agent.

Using saliva for antibody detection brings out new approaches which makes anti-HCV detection easier. Self-saliva collection is one these advantages. User friendly and easy to apply test is cost effective, convenient and time saving compared to complex laboratory test methods which requires highly skilled and experienced laboratory specialist and more accessible in underserved communities and isolated populations (11).

Cost-effectiveness also makes saliva sampling attractive. In a cost-effectiveness study rapid antibody saliva testing costs was determined much more lower when compared to testing via venipuncture (10).

\begin{tabular}{|c|c|c|c|c|c|c|}
\hline Reference & $\begin{array}{l}\text { Saliva collection } \\
\text { device }\end{array}$ & $\begin{array}{l}\text { Anti-HCV antibody } \\
\text { assay }\end{array}$ & $\begin{array}{l}\text { Positive anti-HCV } \\
\text { antibody } \\
\text { number }\end{array}$ & $\begin{array}{l}\text { Negative anti-HCV } \\
\text { antibody } \\
\text { number }\end{array}$ & $\begin{array}{l}\text { Percent sensitivity } \\
(95 \% \mathrm{CI})\end{array}$ & $\begin{array}{l}\text { Percent specificity } \\
(95 \% \text { CI) }\end{array}$ \\
\hline Elsana et al. (6) & No device & Abbott HCV 2.0 & 73 & 52 & 90 & 100 \\
\hline Bello et al. (9) & Salivette & Abbott HCV 3.0 & 152 & 108 & $94(89-97)$ & $99(94-100)$ \\
\hline \multirow[t]{4}{*}{$\begin{array}{l}\text { Van Doornum et } \\
\text { al. (10) }\end{array}$} & Salivette & $\begin{array}{l}\text { Abbott HCV } 3.0 \\
\text { SAVe ELISA }\end{array}$ & 102 & 50 & 77.5 & 98 \\
\hline & Salivette & Monolisa $^{\mathrm{b}}$ & 102 & 50 & 79.4 & 98 \\
\hline & Omni-sal & $\begin{array}{l}\text { O. HCV } 3.0 \text { SAVe } \\
\text { ELISA }^{c}\end{array}$ & 102 & 50 & 76.5 & 98 \\
\hline & Omni-sal & Monolisa $^{\mathrm{b}}$ & 102 & 50 & 76.5 & 94 \\
\hline \multirow[t]{2}{*}{ Judd et al. (11) } & Orasure & $\begin{array}{l}\text { O. HCV } 3.0 \text { SAVe } \\
\text { ELISA }^{c}\end{array}$ & 253 & 392 & $92(87-95)$ & $99(98-100)$ \\
\hline & Salivette & $\begin{array}{l}\text { HCV } 3.0 \text { SAVe } \\
\text { ELISA }^{c}\end{array}$ & 252 & 389 & 74 (62-79) & $99(97-100)$ \\
\hline $\begin{array}{l}\text { Lucidarme et al. } \\
\text { (12) }\end{array}$ & Salivette & Monolisa ${ }^{b}$ & 45 & 63 & 78 & 99 \\
\hline De Cock et al. (13) & Oracol & $\begin{array}{l}\text { O. HCV } 3.0 \text { SAVe } \\
\text { ELISA }^{c}\end{array}$ & 73 & 73 & 89 (79-95) & $100(94-100)$ \\
\hline Amado et al. (5) & Orasure & $\begin{array}{l}\text { United Biomedical } \\
\text { HCV } 4.0 d\end{array}$ & 16 & 89 & $75(47-92)$ & $98(92-99)$ \\
\hline Gonzalez et al. (4) & Orasure & $\begin{array}{l}\text { O. HCV } 3.0 \text { SAVe } \\
\text { ELISA }^{c}\end{array}$ & 45 & 45 & $87(72-94)$ & $100(90-100)$ \\
\hline Moorthy et al. (14) & Omni-sal & $\begin{array}{l}\text { Hepanostika HCV } \\
\text { Ultrad }\end{array}$ & 49 & 93 & 81.5 & 92.5 \\
\hline Present study & In-house device & $\begin{array}{l}\text { O. HCV } 3.0 \text { SAVe } \\
\text { ELISA }^{\circ}\end{array}$ & 75 & 75 & 87 & 87 \\
\hline
\end{tabular}




\section{Study Limitations}

Discrepancies in sensitivity and specificity determined in other studies (Table 2) may be related to collection devices used, study populations and saliva ELISA method employed. Sensitivity and specificity of saliva anti-HCV antibody ELISA was lower in our study compared to literature data, likely related to use of a different method for saliva collection. A comparative study using the collection device of the present study and at least one of the commercially available collection devices should be able to provide an answer.

\section{Conclusion}

A combination of the new saliva collection method with a modified commercial ELISA assay yielded acceptable results. Sensitivity and specificity indicate that this method should be suitable for epidemiological surveys, obviating risk to health personnel using invasive procedure and more acceptable by infants and young children.

\section{Acknowledgements}

We thank Jacqueline Gutenkunst for refining the language of the article and Prof. Dr. Reyhan Ucku for statiscal analysis.

\section{Ethics}

Ethics Committee Approval: The study was approved by the Institutional Ethical Comittee Dokuz Eylül University (approval number: 200895).

Informed Consent: Prior informed consent was obtained from all participating patients, who were $>18$ years of age.

Peer-review: Externally peer-reviewed.

\section{Authorship Contributions}

Surgical and Medical Practices - O.Ö.E.K., Concept: O.Ö.E.K., A.Y., Design: O.Ö.E.K., Z.K., Data Collection or Processing: O.Ö.E.K., Analysis: O.Ö.E.K., Literature Search: O.Ö.E.K., Writing: O.Ö.E.K.

Conflict of Interest: All authors declare to have no conflict of interest.

Financial Disclosure: This study was funded by Dokuz Eylul University (approval number: 200895).

\section{References}

1. World Health Organization, Weekly Epidemiological Record. 1997:72:65-72.

2. World Health Organization, Bulletin. 2012;90:540-550.

3. Ray SC, Thomas DL. Hepatitis C. In: Mandell GL, Bennett JE, Dolin R, (eds). Mandell, Douglas, and Bennett's Principles and Practice of Infectious Diseases. 8th ed. Philadelphia: Churchill Livingstone, 2015:1904-1927.
4. González V, Martró E, Folch C, Esteve A, Matas L, Montoliu Grífols JR, Bolao F, Tural C, Muga R Parry JV, Ausina V, Casabona J. Detection of hepatitis $\mathrm{C}$ virus antibodies in oral fluid specimens for prevalence studies. Eur J Clin Microbiol Infect Dis. 2008;27:121-126.

5. Amado L A, Villar LM, de Paula VS, de Almedia AJ, Gaspar AM. Detection of hepatitis $A, B$, and $C$ virus-specific antibodies using oral fluid for epidemiological studies. Mem Inst Oswaldo Cruz. 2006;101:149-155.

6. Elsana S, Sikuler E, Yaari A, Shemer-Avni Y, Abu-Shakra M, Buskila D, Katzman P, Naggan L, Margalith M. HCV antibodies in saliva and urine. J Med Virol. 1998;55:24-27.

7. Lee SR, Kardos KW, Schiff E, Berne CA, Mounzer K, Banks AT, Tatum HA, Friel TJ, Demicco MP, Lee WM, Eder SE, Monto A, Yearwood GD, Guillon GB, Kurtz LA, Fischl M, Unangst JL, Kriebel L, Feiss G, Roehler M. Evaluation of a new, rapid test for detecting HCV infection, suitable for use with blood or oral fluid. J Virol Methods. 2011;172:27-31.

8. Cha YJ, Park Q, Kang ES, Yoo BC, Park KU, Kim JW, Hwang YS Kim $\mathrm{MH}$. Performance evaluation of the OraQuick hepatitis C virus rapid antibody test. Ann Lab Med. 2013;33:184-189.

9. Bello PY, Pasquier C, Gourney P, Puel J, Izopet J. Assessment of a hepatitis $C$ virus antibody assay in saliva for epidemiological studies. Eur J Clin Microbiol Infect Dis. 1998;17:570-572.

10. Van Doornum G J, Lodder A, Buimer M, Van Ameijden EJC, Bruisten S. Evaluation of hepatitis $C$ antibody testing in saliva specimens collected by two different systems in comparison with HCV antibody and HCV RNA in serum. J Med Virol. 2001;64:1320.

11. Judd A, Parry J, Hickman M, McDonald T, Jordan L, Lewis $K$, Contreras M, Dusheiko G, Foster G, Gill N, Kemp K, Main J, Murray-Lyon I, Nelson M. Evaluation of a modified commercial assay in detecting antibody to hepatitis $\mathrm{C}$ virus in oral fluids and dried blood spots. J Med Virol. 2003;71:49-55.

12. Lucidarme D, Decoster A, Delamare C, Schmitt C, Kozlowski D, Harbonnier J, Jacob C, Cyran C, Forzy G, Defer C, llef D, Emmanuelli J, Filoche B. An inter-laboratory study of anti-HCV antibody detection in saliva samples. Gastroenterol Clin Biol. 2003;27:159-162

13. De Cock L, HutseV, Vranckx R. Correlation between detection of antibodies against hepatitis $C$ virus in oral fluid and hepatitis $C$ virus RNA in serum. Eur J Clin Microbiol Infect Dis. 2005;24:566568.

14. Moorthy M, Daniel HD, Kurian G, Abraham P. An evaluation of saliva as an alternative to plasma for the detection of hepatitis $C$ virus antibodies. Indian J Med Microbiol. 2008;26:327-332.

15. Kimble MM, Stafylis C, Treut P, Saab S, Klausner JD. Clinical evaluation of a hepatitis $C$ antibody rapid immunassay on self-collected oral fluid specimens. Diag Microbiol Infect Dis. 2019;95:149-151

16. Girardin F, Hearmon N, Negro F, Eddowes L,Bruggmann P, Castro E. Increasing Hepatitis C virus screening in people who inject drugs in Switzerland using rapid antibody saliva and dried blood spot testing: a cost-effectiveness analysis. J. Viral Hepat. 2019;26:236-245. 